\title{
HUBUNGAN RINITIS ALERGI DENGAN OTITIS MEDIA AKUT PADA ANAK DI RSUD DR. H ABDUL MOELOEK BANDAR LAMPUNG TAHUN
}

\author{
Muslim Kasim ${ }^{1}$, Arti Febriyani Hutasuhut ${ }^{2^{*}}$, Tan'im Arief $^{3}$, Farah Ulya \\ Suryadana ${ }^{4}$ \\ ${ }^{1}$ Departemen Telinga Hidung Tenggorok Kepala Leher Fakultas Kedokteran \\ Univeritas Malahayati \\ ${ }^{2}$ Departemen Imunologi Fakultas Kedokteran Universitas Malahayati \\ ${ }^{3}$ Departemen Telinga Hidung Tenggorok Kepala Leher Fakultas Kedokteran \\ Universitas Malahayati \\ ${ }^{4}$ Program Studi Kedokteran Fakultas Kedokteran Universitas Malahayati \\ Email Korespondensi: Email: artifebriyani@gmail.com
}

\begin{abstract}
RELATIONSHIP BETWEEN ALLERGIC RHINITIS AND ACUTE OTITIS MEDIA IN CHILDREN IN RSUD DR. H ABDUL MOELOEK BANDAR LAMPUNG
\end{abstract}

Introduction: Background : Acute Otitis Media (AOM) is an inflammation that happen in the middle ear and is very common, especially in children. Children are susceptible to acute otitis media (AOM) due to the shorter and horizontal anatomy of the eustachian tube. Allergic Rhinitis is one of the risk factos that caused acute otitis media in children.

Purpose : The purpose of this study was to determine the correlation between Allergic Rhinitis and Acute Otitis Media in Children

Method: This study used an observational analytic research with cross sectional research design. The sample in this study was 59 patients diagnosed with acute otitis media at RSUD Dr. H. Abdul Moeloek in 2019-2020. The sampling technique used total sampling. Data analysis using Chi-Square test

Result: The results of this study indicated that there was a relationship between allergic rhinitis and acute otitis media in children with $p$ value =

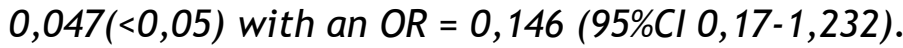

Conclusion: There is a relationship between Allergic Rhinitis and Acute Otitis Media in children at Dr. H Abdul Moeloek Bandar Lampung in 2019-2020

Keyword : Allergic Rhinitis, Acute Otitis Media, Children

\section{INTISARI: HUBUNGAN RINITIS ALERGI DENGAN OTITIS MEDIA AKUT PADA ANAK DI RSUD DR. H ABDUL MOELOEK BANDAR LAMPUNG}

Latar belakang: Otitis Media Akut (OMA) merupakan peradangan yang terjadi pada telinga bagian tengah dan sangat sering terjadi terutama pada anak-anak. Anak-anak rentan terkena Otitis Media Akut (OMA) dikarenakan bentuk anatomi tuba eustachius yang lebih pendek dan horizontal. Rinitis Alergi merupakan salah satu faktor risiko yang menyebabkan Otitis Media Akut pada anak.

Tujuan: Tujuan penelitian ini adalah untuk mengetahui hubungan Rinitis Alergi dengan Otitis Media akut pada Anak.

Metode: Penelitian analitik observasional dengan desain penelitian cross sectional. Sampel sebanyak 59 pasien dengan diagnosa otitis media akut anak di 
RSUD Dr. H. Abdul Moeloek tahun 2018. Teknik pengambilan sample menggunakan total sampling. Analisis data menggunakan uji Chi-Square

Hasil : Hasil penelitian ini menunjukkan bahwa terdapat hubungan antara rinitis alergi dengan otitis media akut pada anak dengan $p$ value $=0,047(<0,05)$ dengan nilai OR $=0,146(95 \% \mathrm{Cl} 0,17-1,232)$.

Kesimpulan : Terdapat hubungan antara Rinitis Alergi dengan Otitis Media Akut pada anak di RSUD Dr. H Abdul Moeloek Bandar Lampung tahun 2019-2020

Kata Kunci : Rinitis Alergi, Otitis Media Akut, Anak

\section{PENDAHULUAN}

Otitis Media Akut merupakan peradangan telinga tengah yang sering disebabkan oleh bakteri atau virus dan berhubungan erat dengan infeksi hidung serta tenggorokan. (Tortora dan Derrickson, 2012). Anak - anak rentan terkena otitis media akut dikarnakan bentuk anatomi tuba eustachius nya yang lebih pendek, lebar dan letaknya lebih horizontal dari tuba eustachius orang dewasa, sehingga sangat memungkinkan bakteri patogen yang berasal daari nasofaring masuk kedalam tuba eustachius lalu membentuk kolonisasi dan menyebabkan terjadinya infeksi pada telinga bagian tengah. (Qureishi, et al 2014). Insiden penyakit ini sedikit lebih tinggi ditemukan pada anak laki-laki bandingkan perempuan. (Cheong et al, 2012).

Sebuah penelitian oleh Waseem, (2014), menunjukkan bahwa kurang lebih 20 juta anak anak terkena otitis media akut setiap tahunnya. Di Asia Tenggara, Indonesia merupakan negara urutan keempat dengan prevalensi gangguan telinga tertinggi sebesar $(4,6 \%)$. Tiga negara lainnya adalah Sri Langka $(8,8 \%)$, Myanmar $(8,4 \%)$ dan India ( 6.3\%). (Samuel et al., 2013). Menurut penelitian yang dilakukan di RSUP Sanglah Denpasar periode Januari - Desember tahun 2014, didapatkan hasil bahwa insiden terjadinya OMA pada anak laki-laki sebanyak 46 orang $(59,7 \%)$ terkena OMA, sedangkan pada anak perempuan sebanyak 31 orang (40,2\%). (Mahardika, 2014). Penelitian di Indonesia yang berada di Kota Bali di poli THT RSUP Sanglah Denpasar pada periode Januari sampai Desember sampai Februari 2014, sebanyak 77 orang pasien yang didiagnosis terkena Otitis Media Akut (OMA). Kelompok usia kurang dari 2 tahun adalah yang paling tinggi, sebanyak $(38,, 9 \%)$. Kelompok usia 2 - 5 tahun sebanyak (16,8\%). Kelompok usia 5 - 12 tahun adalah sebanyak (25,9\%), dan anak anak yang berusia 12 - 18 tahun adalah (3,8\%) (Mahardika, 2014).

Beberapa hal menyebabkan anak - anak mengalami otitis media adalah genetik, infeksi, sistem imun tubuh serta faktor lingkungan (Gotthelf, 2015). Biasanya bakteri yang paling sering ditemukan pada kultur cairan telinga tengah anak penderita otitis media akut adalah Streptococcus pneumonia, Haemophilus influenza, dan Moraxellaa catarrhalis. (Gotthelf, 2015).

Rintis Alergi merupakan salah satu penyakit atopi yang termasuk dalam penyakit kronis pada anak dikarnakan insidensi nya yang terus bertambah selama beberapa tahun terakhir. (Mahardika et al., 2014).

Rinitis Alergi adalah salah satu faktor risiko untuk terjadinya Otitis Media Akut (OMA) pada anak. Penelitian yang dilakukan oleh (Byeon H, 2019) mengatakan 
$(23,3 \%)$, kemudian diikuti kelompok usia > 5-12 dan > 12-18 tahun sebanyak 5 orang $(16,7 \%)$.

Tabel 2. Distribusi Frekuensi Otitis Media Akut pada Anak akibat Rinitis Alergi berdasarkan Usia di Poli THT-KL RSUD Dr. H. Abdul Moeloek Bandar Lampung tahun 2019-2020

Berdasarkan tabel 2 diketahui bahwa distribusi frekuensi otitis media akut pada anak akibat rinitis alergi berdasarkan jenis kelamin pada anak di poli THT-KL RSUD Dr. H Abdul Moeloek Bandar Lampung tahun 2019-2020, jenis kelamin lakilaki merupakan pasien terbanyak yaitu berjumlah 19 orang.

\section{Analisis Bivariat}

Tabel 3. Hubungan Rinitis Alergi

\begin{tabular}{ccccccc}
\hline \multicolumn{4}{c}{ Otitis Media Akut } \\
$\begin{array}{c}\text { Jenis } \\
\text { Ya RA }\end{array}$ & \multicolumn{2}{c}{ Tidak RA } & \multicolumn{2}{c}{ Total } \\
$\begin{array}{c}\text { Kela } \\
\text { min }\end{array}$ & N & $\%$ & N & $\%$ & N & $\%$ \\
\hline Laki-Laki & 19 & 63,3 & 13 & 44,8 & 32 & 54,2 \\
$\begin{array}{c}\text { Perempu } \\
\text { an }\end{array}$ & 11 & 36,7 & 16 & 55,2 & 27 & 45,8 \\
Total & 30 & 100 & 29 & 100 & 59 & 100 \\
\hline
\end{tabular}

dengan Otitis Media Akut pada Anak di Poli THT-KL RSUD Dr. H. Abdul Moeloek Bandar Lampung tahun 2019-2020

\begin{tabular}{|c|c|c|c|c|c|c|c|c|}
\hline \multirow[b]{3}{*}{$\begin{array}{l}\text { Rinitis } \\
\text { Alergi }\end{array}$} & \multicolumn{6}{|c|}{ Otitis Media Akut } & \multirow[b]{3}{*}{$\begin{array}{l}p- \\
\text { valu } \\
e\end{array}$} & \multirow[b]{3}{*}{ OR } \\
\hline & \multicolumn{2}{|r|}{ Ya } & \multicolumn{2}{|c|}{ Tidak } & \multicolumn{2}{|c|}{ Total } & & \\
\hline & $\mathrm{N}$ & $\%$ & $\mathrm{~N}$ & $\%$ & $\mathrm{~N}$ & $\%$ & & \\
\hline$Y_{z}$ & 2 & 72,5 & 11 & 27,5 & 40 & 100 & & \\
\hline Tid & 18 & 94,7 & 1 & 5,3 & 19 & 100 & 0,04 & \\
\hline Total & 47 & 79,7 & 12 & 20,3 & 59 & 100 & & $\begin{array}{l}(0,17- \\
, 232)\end{array}$ \\
\hline
\end{tabular}

Berdasarkan tabel 3, hasil analisis uji chi square dari 40 orang yang mengalami Rinitis Alergi terdapat sebanyak 29 orang $(72,5 \%)$ mengalami Otitis Media Akut, sedangkan dari 19 orang yang tidak mengalami Rintis Alergi terdapat sebanyak 18 orang (94,7\%) yang mengalami Otitis Media Akut. Hasil uji statistik diperoleh $p$ value $=$ $0,047<0,05$ dengan nilai $\mathrm{OR}=0,146$ $(95 \% \mathrm{Cl} \quad 0,19-1,352)$ yang berarti terdapat hubungan rinitis alergi dengan otitis media akut pada anak di RSUD Dr. H Abdul Moeloek Bandar Lampung tahun 2019-2020.

\section{PEMBAHASAN}

\section{Univariat}

Berdasarkan tabel 1 distribusi frekuensi usia otitis media akut pada anak akibat rinitis alergi pada anak di RSUD Dr. H Abdul Moeloek Bandar Lampung tahun 2019-2020, didapatkan dari total 59 sampel, paling banyak terkena pada kelompok usia $\leq 2$ tahun sebanyak 13 orang $(43,3 \%)$, dan kelompok usia paling sedikit > 12-18 tahun sebanyak 5 orang $(16,7 \%)$. Hal ini sejalan dengan penelitian yang dilakukan oleh oleh (Mahardika, 2014), dimana proporsi tertinggi pada usia $\leq 2$ tahun sebanyak 30 orang $(38,9 \%)$ dan paling sedikit pada usia $>12-18$ tahun sebanyak 3 orang $(3,8 \%)$. Menurut teori, peningkatan risiko otitis media akut disebabkan oleh keadaan anatomi tuba eustachius yang lebih pendek dan lebih horizontal pada anak-anak lebih muda dibandingkan dengan dewasa, selain itu karena faktor imunitas anak yang belum bekerja dengan baik. (Shaikh dan Hoberman, 2010)

Berdasarkan tabel 2 distribusi frekuensi jenis kelamin otitis media akut pada anak akibat rinitis alergi pada anak di RSUD Dr. H Abdul Moeloek Bandar Lampung tahun 2019-2020, didapatkan dari total 59 sampel, proporsi pada laki laki lebih tinggi, yaitu sebanyak 19 orang $(32,2 \%)$ lalu proporsi paling sedikit pada perempuan, yaitu 
sebanyak 11 orang $(36,7)$. Hasil penelitian ini sejalan dengan penelitian yang dilakukan oleh (Byeon H, 2018), dimana proporsi jenis kelamin tertinggi pada lakilaki yaitu sebanyak $(50,5 \%)$ dan perempuan $(49,5 \%)$.

\section{Bivariat}

Berdasarkan hasil uji statistik chi square menunjukkan bahwa dari 41 orang pasien yang mengalami rinitis alergi terjadi otitis media akut yaitu (72,5\%). Nilai $\mathrm{p}$-value $0,047(\mathrm{p}<0,05)$, artinya $\mathrm{Ha}$ diterima, maka dapat disimpulkan bahwa terdapat hubungan rinitis alergi dengan otitis media akut pada anak di RSUD Dr. H1 Abdul Moloek Bandar Lampung tahun 2019-2020 dengan nilai $\mathrm{OR}=0,146(95 \% \mathrm{Cl} 0,17$ 1,232 ) yang artinya pasien dengan rinitis alergi berpeluang 0,146 kali lebih berisiko terkena otitis media akut daripada pasien yang tidak mengalami rinitis alergi. Menurut Nagel (2012), gejala klinis rinitis alergi disebabkan oleh mediator kima. Mediator yang memiliki peranan besar adalah Histamin. Histamin akan menyebabkan hidung gatal, bersin-bersin, rinore cair dan hidung tersumbat. Rinitis alergi bersifat kronik dan presisten sehingga dapat menyebabkan perubahan berupa hipertrofi dan hiperplasi epitel mukosa dan dapat menimbulkan komplikasi seperti otitis media, sinusitis, polip nasal (Djafar et al 2018). Hal ini sejalan dengan penelitian yang dilakukan oleh (Basyir et al., 2014) yang menyatakan bahwa rinitis alergi selain terjadi di kavum nasi juga meluas ke nasofaring dan tuba eustachius sehingga dapat mengganggu fungsi tuba eustachius, yang berakibat menyebabkan terjadinya otitis media apabila tidak ditangani dengan baik, sehingga bakteri dengan cepat menyebar ke telinga bagian tengah dan menyebabkan otitis media akut.

\section{KESIMPULAN DAN SARAN}

Berdasarkan hasil penelitian dan pembahasan, maka dapat diambil kesimpulan didapatkan kesimpulan bahwa terdapat hubungan antara rintis alergi dengan otitis media akut pada anak di RSUD Dr. H Abdul Moeloek Bandar Lampung tahun 2019-2020.

Bagi peneliti selanjutnya diharapkan dapat mengembangkan penelitian ini ataupun memperluas penelitian di tempat yang berbeda, memperbanyak sampel penelitian serta menggunakan faktor-faktor risiko lainnya sebagai variabel dalam penelitian.

\section{DAFTAR PUSTAKA}

Basyir, P. B. S., Madiadipoera, T., \& Lasminingrum, L. (2014). Angka Kejadian dan Gambaran Rinitis Alergi dengan Komorbid Otitis Media di Poliklinik Rinologi Alergi Departemen IImu Kesehatan THT-KL RS Dr. Hasan Sadikin. Tunas Medika Jurnal Kedokteran \& Kesehatan, 3(1).

Byeon, H. (2019). The association between allergic rhinitis and otitis media: A national representative sample of in South Korean children. https: / / doi.org/10.1038/s4 1598-018-38369-7. 25 Januari 2021.

Cheong KH, \& Hussain SS. (2012). Management of recurrent acute otitis media in children: systematic review of the effect of different interventions on otitis media recurrence, recurrence frequency and total recurrence time. The journal of laryngology \& 
otology, 126(9), 874-85.

Djafar, Z. A, Helmi, \& Restuti, R. D. (2018). Buku Ajar Ilmu Kesehatan Telinga Hidung Tenggorok Kepala \& Leher. $\left(7^{\text {th }}\right.$ ed). Jakarta: Balai Penerbit FKUI.

Gotthelf, L. N. (2015). Diagnosis and treatment of otitis media. https://doi.org/10.1016/j.c vsm.2003.10.007. 14 Oktober 2020.

Mahardika, I. W. P., Sudipta, I. M., Wulan, S., Sutanegara, D., \& Denpasar, S. (2019). Karakteristik Pasien Otitis Media Akut di Rumah Sakit Umum Pusat Denpasar Periode Januari - Desember Tahun 2014. E-Jurnal Medika, 8(1), 51-55.

Nagel, Patrick. (2012). Dasar-dasar IImu THT edisi 2: Jakarta: EGC

Qureishi, A., Lee, Y., Belfield, K., Birchall, J. P., \& Daniel, M. (2014). Update on otitis media - Prevention and treatment. Infection and Drug Resistance, 7, 15-24.

Samuel, S., Kardinan N., Soeng S. (2013). Karakteristik Pasien Rawat Inap Otitis Media Akut di Rumah Sakit Immanuel Bandung Periode JanuariDesember 2013. Skripsi. Universitas Maranatha, Bandung.

Shaikh, N. And Hoberman. A. (2010). Update: Acute Otitis Media. Pediatric Ann.

Tortora, G., \& Derrickson, B. (2012). Principles of Anatomy \& Physiology $13^{\text {th }}$ Edition. In Principles of Anatomy \& Physiology $13^{\text {th }}$ Edition.

Waseem, M. (2014). Otitis Media Treatment. http://emedicine.medsca pe.com/article/994656ov erview\#aw2aab6b2b3aa.

10 Oktober 2020. 